\title{
A FRAMEWORK FOR SUCCESSFUL NEW PRODUCT DEVELOPMENT
}

\author{
C. Pienaar ${ }^{1 *}$, E. van der Lingen ${ }^{1} \&$ E. Preis ${ }^{1}$
}

\section{ARTICLE INFO}

Article details

Presented at the $30^{\text {th }}$ annual conference of the Southern African Institute for Industrial Engineering (SAIIE), held from

30 September - 2 October 2019 in Port Elizabeth, South Africa

Available online

15 Nov 2019

Contact details

Corresponding author

u17377227@tuks.co.za

Author affiliations

1 Department of Engineering and

Technology Management,

Graduate School of Technology

Management, Faculty of

Engineering, Built Environment

and IT, University of Pretoria,

South Africa

DOI

http://dx.doi.org/10.7166/30-3-2239
ABSTRACT

To exploit the competitive advantage of a core competency, such as new technology development, an organisation must be capable of developing that technology efficiently and effectively. The purpose of this research was to study the new product development success and failure factors in a chemical company, and recommend improvements to the existing new product development framework. The study is significant in that new product development performance needs to be improved to remain competitive in the current economic and environmental climate. The same new product development model is applied to all projects in the company under investigation. A preliminary investigation suggested that the success rate of these projects fluctuates significantly. Qualitative case study research was conducted through semistructured face-to-face interviews. A thematic approach was used to organise and interpret the interview data. As the data was coded, several sub-themes emerged, and from these themes critical success factors and critical failure factors were identified. All of these factors were discussed and compared against the literature for relevance. The critical success factors and critical failure factors were divided into three categories: input requirements, stage kickoff guidelines, and continuous prompts. In this format these factors are recommended as potential improvements to the organisation's existing new product development framework.

\section{OPSOMMING}

Om die mededingende voordeel van ' $n$ kernbevoegdheid, soos nuwe tegnologie-ontwikkeling te benut, moet ' $n$ organisasie die tegnologie doeltreffend en effektief kan ontwikkel. Die doel van hierdie navorsing is om die nuwe produkontwikkelingsukses en faktore in 'n chemiese maatskappy te bestudeer en verbeterings aan te beveel aan die bestaande nuwe produkontwikkelingsraamwerk. Die studie is beduidend deurdat nuwe produkontwikkelingsprestasie verbeter moet word om mededingend te bly in die huidige ekonomiese- en omgewingsklimaat. Dieselfde nuwe produkontwikkelingsmodel word toegepas op alle projekte in die maatskappy wat ondersoek word. Voorlopige ondersoek het voorgestel dat die sukseskoers van hierdie projekte aansienlik wissel. Kwalitatiewe gevallestudie-navorsing is uitgevoer deur middel van semi-gestruktureerde aangesig-tot-aangesig onderhoude. 'n Tematiese benadering is gebruik om die onderhoudsgegewens te organiseer en te interpreteer. Namate die data gekodeer is, het verskeie subtemas na vore getree, en uit hierdie temas is kritiese sukses- en kritiese mislukkingsfaktore identifiseer. Al hierdie faktore is bespreek en vergelyk met die literatuur vir relevansie. Die kritiese sukses- en kritiese mislukkingsfaktore is in drie kategorieë verdeel: insetvereistes, fase afskop riglyne, en deurlopende vrae. In hierdie formaat word hierdie faktore aanbeveel as moontlike verbeteringe aan die organisasie se bestaande nuwe produkontwikkelingsraamwerk. 
The global economic downturn motivates companies to scrutinise their research and development (R\&D) budgets. R\&D is always an attractive target for budget cuts during downturns, since it does not produce cash directly. Development groups are mistakenly asked to cut costs across the board, to 'spread the misery' in a fair way [1]. Since the collapse of the crude oil price, chemical companies have been under severe pressure. The operating profit of the company studied here fell by 48 per cent in the 2016 financial year (FY16) due to difficult and unpredictable global markets. This company embarked on a strategy to cut costs from 2012, which enabled it to sustainably endure a lower-for-longer oil price environment [2].

Companies should use the challenging economic environment as an opportunity to improve their R\&D focus, practice, and management. The aim should not only be to cut costs, but also to increase productivity, speed up time to market, and position the organisation for greater success in future [1]. Cost cutting induces a resource crunch, and this could be crippling to new product development (NPD). It leads to projects taking too long to market, under-performing new products, and portfolios that contain numerous low-value projects. To endure and overcome economically challenging times, NPD resources should rather be managed and allocated strategically, tactically, and via proper portfolio management [3].

NPD is seen as the activities that can convert ideas, market opportunity, and a set of assumptions about a certain technology into a product available for sale $[4,5]$. It is vital for organisations to perform NPD effectively and efficiently in order to stay competitive in today's economic and environmental climate. Initial indications showed that the success rate of NPD in the company under investigation can fluctuate considerably, even though the same NPD management model is applied to all projects.

A 2011 US benchmarking study showed that new products launched in 2008 accounted for 27.3 per cent of company sales at the time of this study [6]. A survey of executive opinion also showed that innovation is now the foremost driver of organisational growth and success. Fifteen years ago, the number one driver was cost cutting. This benchmarking study also revealed that only 53.2 per cent of NPD projects meet cost performance targets, and only 44.4 per cent stay on schedule [6]. It has been shown that 'the best' firms use NPD tools more often than 'the rest'; however, their success rate has not increased above 61 per cent in the past 25 years [7]. It seems that there is some disconnect between the use of NPD tools and the success rate of NPD projects [8].

In this study, the aim was to determine whether project success can be linked to certain common elements, and to ensure that these elements are captured in the NPD governing tool that is relevant to the company under investigation. Several critical success factors (CFS) and critical failure factors (CFF) could be identified, which are not explicitly captured by the current NPD process.

\section{THEORETICAL BACKGROUND}

Product development is the sum of many factors, such as an organisation's development strategy, the culture of the organisation, the resources available, and the chosen NPD model. NPD models are tools that govern and play a central role in the product development process [9]. Several NPD models - such as stage gate, agile, and lean - exist today, and are at times combined into hybrid versions [10]. When assessing the NPD performance of a company, it is important to understand what NPD models are available and may be employed by the company.

\subsection{NPD process}

Many scholars have claimed that a formal NPD process is only suitable for incremental product improvements, and is less beneficial for radical innovation. Griffin, Price, Vojak and Hoffman [11] proposed that such statements are made when the impact of the fuzzy front end (FFE) of innovation is disregarded. The FFE is the chaotic, messy up-front stage of innovation, prior to the formal NPD process. With incremental improvements, the FFE is evolutionary or non-existent. Therefore it appears that formal NPD processes are more suited to these types of innovation. For radical innovations, it is important that sufficient time and focus is allocated to the FFE, and that the transition from the FFE to the formal NPD process is managed properly [11]. 
The literature shows that following a formal NPD process is one of the main best practices applied by top companies. There are, however, various types of NPD process, and no one type consistently outperforms the rest [5].

Top performing companies ultimately distinguish themselves by learning from others, adapting practices to their own needs, and seeking continuous improvement [10]. An innovation culture is required in which failure is understood, and learning through failing-forward is valued [12]. The question is not whether stage gate, agile, or lean is the best NPD process, but rather what blend of practices suits a company best [10].

The chemical company being studied in this research project already employs a structured NDP process - the stage gate model. Stage gate is a highly disciplined NPD model that follows a sequential process with a strict order of activities. The process starts with idea generation, progresses via formal gate reviews, and is completed when the product is launched [10]. Having a formal NPD process is likely one of the main contributing factors to the company's success in technology development.

Stage gate was introduced in the 1980s to improve new product management in the face of increasing competition, maturing markets, and the increased rate of technological change. It is both a conceptual and an operational model for transferring a new product from idea to launch [13]. When the stage gate model was introduced, it became the second-generation NPD process at that time. The first-generation NPD process was NASA's phased project planning (PPP) process, commonly referred to as the 'phased review process' (PRP) [14]. Over the years, the stage gate model evolved through various successive generations, as innovation evolved from a simple, linear technology push to a more integrated balance between technology push and market pull, with interaction between stakeholders and stages [15]. The second-generation model was updated to include practices of fluidity, adaptability, conditional and situational fuzzy gates, a sharper focus on resources and management of portfolios, and more flexibility. Through these updates, the third-generation NPD process was established [16].

The most recent update to the stage gate model is the collaboration with the agile model, which originates from the information technology industry. The traditional linear stage gate model cannot support the iterative cycles and external collaboration required for today's evolving NPD processes. A hybrid process, combining elements of agile and stage gate models, offers more flexibility [17]. This update may be the most exciting and noteworthy change to NPD processes since the introduction of gating systems more than 30 years ago [18].

The organisation studied here uses a stage gate model that is most similar to the second-generation NPD model (Figure 1).

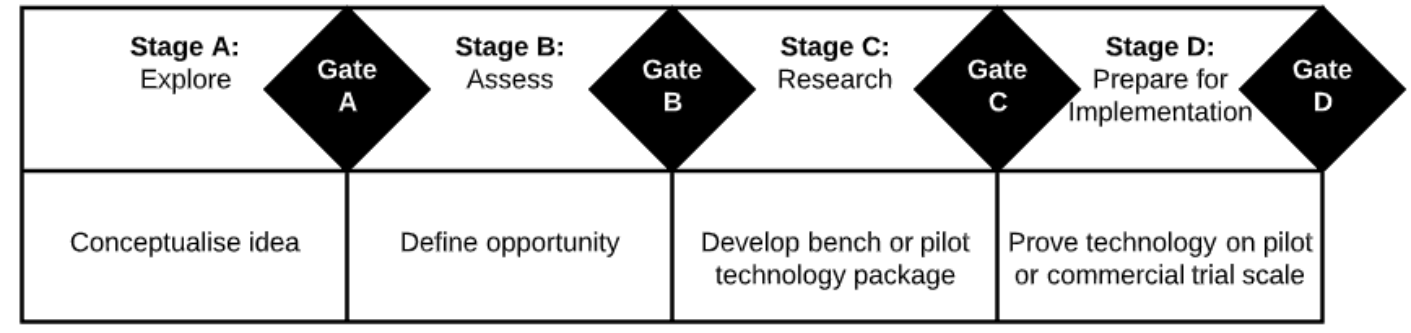

Figure 1: The stage gate model, as used by the company under investigation

\subsection{NPD best practices}

NPD benchmarking studies are often used to identify industry best practices. These are practices that are consistently prevalent in best-performing businesses. They enable more efficient and effective delivery of new products, and may be the distinguishing factor between success and failure [5]. It is therefore vital to know what these practices are, and to establish whether an organisation follows or lacks such practices. 
The following factors for successful NPD are noted in various literature reviews and benchmarking studies [7, 19-26]:

- $\quad$ NPD strategy: This establishes a vision and focus for R\&D product development and technology management efforts (aligned to the overall company strategy, vision, and focus).

- $\quad$ Company or innovation culture, people, and project climate: To promote product development thinking and collaboration with external associates, clientele, and suppliers.

- Market research: To understand competitors, customers, and external forces in the marketplace.

- $\quad$ Front end innovation practices: To understand customer needs via formal processes for idea assessment and open innovation.

- $\quad$ Portfolio management: To select projects and to ensure on-going balancing across projects.

- NPD process (stage gate, agile, lean, etc.) and commercialisation: To drive new product development, adopt flexibility, and have management understand and support the new products process.

- $\quad$ Metrics and performance evaluation: To measure, track, and share the product development project and programme performance.

Numerous auditing tools have been developed to assess an organisation's NPD performance against best practices [5, 25, 27-30]. Some of these tools are deployed by experienced consultants or practitioners, while others are fully available in the open literature for self-assessment.

An opportunity and need exists to evaluate the NPD performance of selected projects of the chemical company in question against the literature and industry best practices. NPD auditing tools and best practices are available in the literature to use as a basis for this evaluation.

\section{METHODOLOGY}

Qualitative case study research was selected to investigate this research problem. This method allowed the researcher to explore the phenomenon within its context, via a variety of data sources. Due to its flexible and rigorous nature, this approach is well-suited to developing theory, evaluating programmes, and developing interventions [31].

\subsection{Sampling}

The target population of this study is projects from a South African chemical company - particularly projects in the research and technology business unit involved in developing technology offerings via the stage gate process. The targeted sample consists of four projects that have passed through gate $D$ (Figure 1) in the past 10 years. Two of the projects are deemed successful by the organisation, and two unsuccessful. Purposive non-probability sampling was used for this study.

\subsection{Compiling interview questions}

Interview questions were compiled based on the literature studied, focusing specifically on NPD best practices.

\subsection{Gathering case study information}

To preserve anonymity, generic identifiers were allocated to the respondents, such as Participant $A, B, C$ informing on Project A, B and C. To engage fully with the respondents, each interview was recorded. After each session, the interview was transcribed and coded before the next interview was conducted.

\subsection{Data analysis}

A thematic approach was used to organise and interpret the interview data, using qualitative data analysis software (Atlas.ti). The data was cut and arranged into meaningful units of interpretation by inductively looking for key phrases, terms, and practices. This allowed themes to emerge from the data that could be matched to existing themes from the literature [32].

\subsection{Validity}

Generalisability was established by comparing the research results with relevant literature, and using multiple cases to replicate the results [33]. Respondent validation was also used to afford participants the opportunity to check the results for inconsistencies and to challenge the 
researcher's assumptions [34]. This was done using a focus group session in which feedback on the interview results was shared.

\section{$4 \quad$ RESULTS AND DISCUSSION}

At the start of each interview, the participant was asked to describe why they believed the specific project could be classified as either successful or unsuccessful. This information was used to establish why these projects were classified as they were (Table 1). The successful projects studied here met most of the criteria for success, whereas the less successful projects did not necessarily meet all or most of the criteria. Project $D$ most recently passed through gate $D$, and is still in the process of being implemented on a commercial scale.

Table 1: Attributes of success of each project studied for this work.

\begin{tabular}{|c|c|c|c|c|}
\hline Attribute of success & 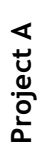 & 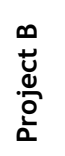 & 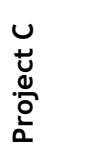 & 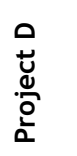 \\
\hline Intended scope implemented & $\mathbf{x}$ & $\checkmark$ & $x$ & $\checkmark$ \\
\hline Implemented/commercialised on time and on budget & $x$ & $\checkmark$ & $x$ & $\checkmark$ \\
\hline Meeting intended performance targets & $x$ & $\checkmark$ & 1 & $\checkmark$ \\
\hline Economics, creating/adding value through the project & $\times$ & $\checkmark$ & $x$ & 2 \\
\hline
\end{tabular}

1) Only after resolving many issues on commercial implementation.

2) Not yet commercially implemented.

The interview discussions were guided along six dimensions or themes (Figure 2 ) that the literature showed to be important to NPD success. The findings from the dimensions of Company Culture and Project Climate were combined into one theme. As the data was coded, sub-themes were identified within these themes along with several CSFs and CFFs (also shown in Figure 2).

\section{CSF \#1: Resource balancing}

Projects can struggle despite high prioritisation, sometimes even receiving too many resources. Initial low prioritisation can, on the other hand, be beneficial to a project and enable success. This is achieved by allowing the project team to do sufficient ground work with a low resource spend, which sets the team up for success in later development stages and for rapid commercialisation.

\section{CSF \#2: Relationship management}

Good market research and fostering good relationships with all stakeholders (potential customers, joint venture partners, suppliers, and business sponsors) is vital to success. It includes fostering a good relationship, maintaining good communication, and ensuring that customer needs are properly understood. It also includes managing the way contracts are set up and enforced. Having proper contracts in place is essential, but it should not be a substitute for relationship.

\section{CSF \#3 and 4: Appropriate concept testing and understanding risk}

Establishing an appropriate scope for concept testing and understanding the project risks enables success. If concept testing is not properly scoped, key scale-up issues may not be identified; this may severely impact cost and schedule later in the project. It is important to follow a structured risk identification process in which all relevant stakeholders are involved, to ensure that all crucial risks are identified and receive the correct priority for risk treatment.

\section{CSF \#5: Flexible NPD process}

Flexibility in the NPD process and frequent discussions are enablers of project success. It is beneficial to involve customer inputs, at least to some extent. When targets are updated as development progresses, it is important also to include customers in these decisions.

\section{CSF \#6: Interim reviews}

Interim reviews are an important tool to keep stakeholders informed of project progress, so that they receive input to enable the project to stay on course. If customer needs change or were not defined correctly in the first place, the interim review will serve as a platform to identify this discrepancy. 


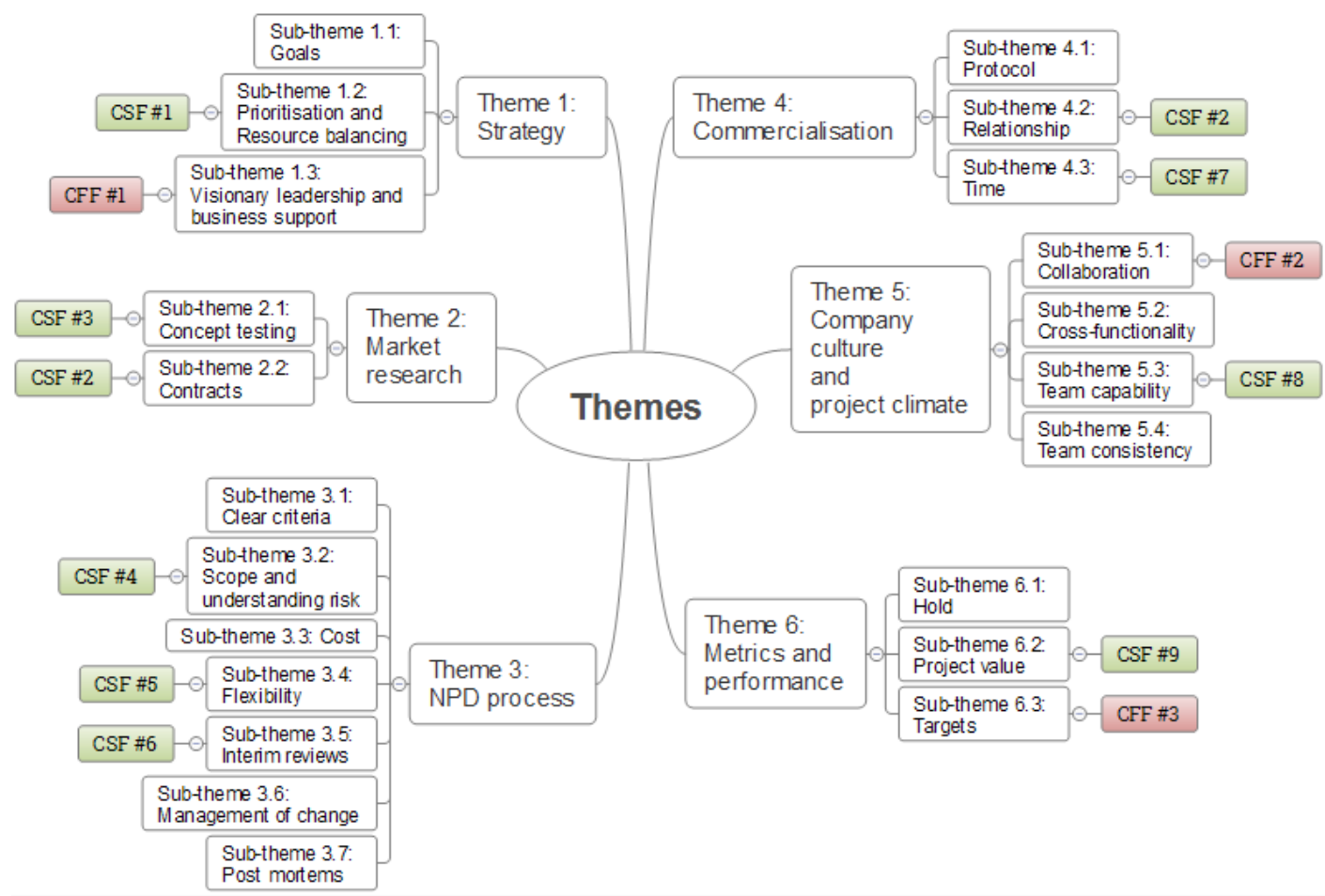

Figure 2: Themes and sub-themes identified from interview data, coupled with the CSFs and CFFs identified from the data

CSF \#7: Minimise commercialisation time

Commercialisation time should be minimised as much as possible. The project may become misaligned with company strategy when it is delayed and the company is not deriving value from it. The market conditions may also change and render the project business case less favourable.

\section{CSF \#8: Team capability}

Team capability and the attributes and management of the team are vital to project success. Having an engaged team in an organisation that fosters engagement is important to outperforming competitors.

\section{CSF \#9: Managing development cost}

Tracking project value-add throughout development is becoming increasingly important. Clear targets should be set on the allowable development spend to ensure that development cost does not outweigh the value it adds to the organisation. Proper portfolio management should be applied in selecting which development projects to pursue.

\section{CFF \#1: Lack of visionary leadership}

Continued visionary leadership or business support is required for NPD to succeed through all its development phases. Fostering good relationships with the business sponsor and meeting development targets aids in sustaining business support and remaining aligned with the business strategy.

\section{CFF \#2: Poor collaboration with external partners}

External collaboration is required to gain a competitive advantage through leveraging the capabilities of external suppliers and customers via collaboration. A company seldom possesses all the capabilities required in a NPD project. Today, when short commercialisation times are vital to success, it is important to be able to leverage external capabilities rather than developing these capabilities internally.

\section{CFF \#3: Adjusting unmet targets}

While flexibility in the NPD process is important, one should take care not to adjust the original targets when they seem to become unattainable as development progresses. This will erode the 
project value-add, and might allow the team to settle for less than what can truly be achieved. On the other hand, adjusting targets through continuous interaction with the customer can ensure that customer needs are still understood, and can be met when the project is complete.

The CSFs and CFFs that were identified are summarised in Table 2, showing their links to the four NPD projects studied here.

Table 2: CSFs and CFFs for NPD, derived from the data

\begin{tabular}{|c|c|c|c|c|}
\hline Attribute & $\stackrel{4}{\stackrel{4}{ \pm}}$ & 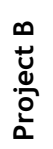 & 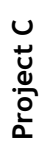 & 藏 \\
\hline $\begin{array}{l}\text { CSF \#1a: Correct amount of resources at the correct stage } \\
\text { CSF \#1b: Sufficient front end time, at low resource intensity }\end{array}$ & $x^{1}$ & $\begin{array}{l}-1 \\
\checkmark \\
\checkmark\end{array}$ & $x^{1}$ & $\checkmark$ \\
\hline $\begin{array}{l}\text { CSF \#2a: Understanding customer needs } \\
\text { CSF \#2b: Good communication and relationship with stakeholders } \\
\text { CSF \#2c: Contract management }\end{array}$ & $\begin{array}{l}x \\
x \\
x\end{array}$ & $\begin{array}{l}\checkmark \\
\checkmark \\
\checkmark\end{array}$ & $x$ & $\checkmark$ \\
\hline CSF \#3: Appropriate concept testing & $x$ & & $x$ & $\checkmark$ \\
\hline CSF \#4: Correct scope definition and understanding of risk & & $\checkmark$ & $x$ & $\checkmark$ \\
\hline CSF \#5: Flexibility in execution of the NPD process & $\sqrt{2}$ & $\checkmark$ & & $\checkmark$ \\
\hline CSF \#6: Interim reviews to track and discuss progress & $x$ & $\checkmark$ & $x$ & $\checkmark$ \\
\hline CSF \#7: Short commercialisation time & $x$ & $\checkmark$ & $x$ & \\
\hline CSF \#8: Capabilities and attributes of team members & & & $x$ & $\checkmark$ \\
\hline \multicolumn{5}{|l|}{ CSF \#9: Maintain development cost as a function of project value } \\
\hline CFF \#1: Lack or loss of visionary leadership & $\checkmark$ & & $\checkmark$ & \\
\hline CFF \#2: Poor collaboration with external partners & & $x$ & $\checkmark$ & \\
\hline CFF \#3: Adjusting targets once original targets appear to become unattai & $\checkmark$ & $x$ & $\checkmark$ & $x$ \\
\hline
\end{tabular}

1) Received high priority and many resources at first, but resources were reallocated to tend to a commercial crisis.

2) Flexibility helped, but also allowed the team to adjust the target and reduce the value proposition.

To replicate the success that was unlocked by the CSFs identified in this study, and to avoid the failures caused by the CFFs in these projects, improvements to the existing NPD framework are recommended (Figure 3). The recommendations are divided into three categories: input requirements, stage kick-off guidelines, and continuous prompts.

\subsection{Input requirements}

- $\quad$ CSF \#8: Team capability

Internal coordination may not necessarily be ensured with the use of a NPD tool. It may, however, be promoted by assigning experienced or well-suited project leaders and providing them with the necessary training in skills, such as breaking down complex problems and integrating numerous tasks to form a coherent whole. It is also advantageous to have at least a few experienced team members on a project to ensure that these skills are transferred to less experienced individuals. It is therefore recommended that the organisation studied take care when selecting project leaders and teams, and provide training where necessary.

\subsection{Stage kick-off guidelines}

\section{- $\quad$ CSF \#1: Resource balancing}

It is proposed that a recommended resource load per stage, and per project, be given. This resource load should be based on the allowable development cost and complexity of the project. Lower resource intensity and more freedom should be given during front end development phases.

- $\quad$ CSF \#3 and 4: Appropriate concept testing and understanding risk

Good market research and customer participation are much more beneficial when a team has the ability to absorb the information and transform and assimilate it in order to derive knowledge from it. Assimilating market research and customer requirements is one of the ways in which project risks can be identified, understood, and subsequently fed into the scoping of concept tests so that these risks are addressed. It is important, at least at the start of each phase, to establish what is in scope and what is out of scope. 


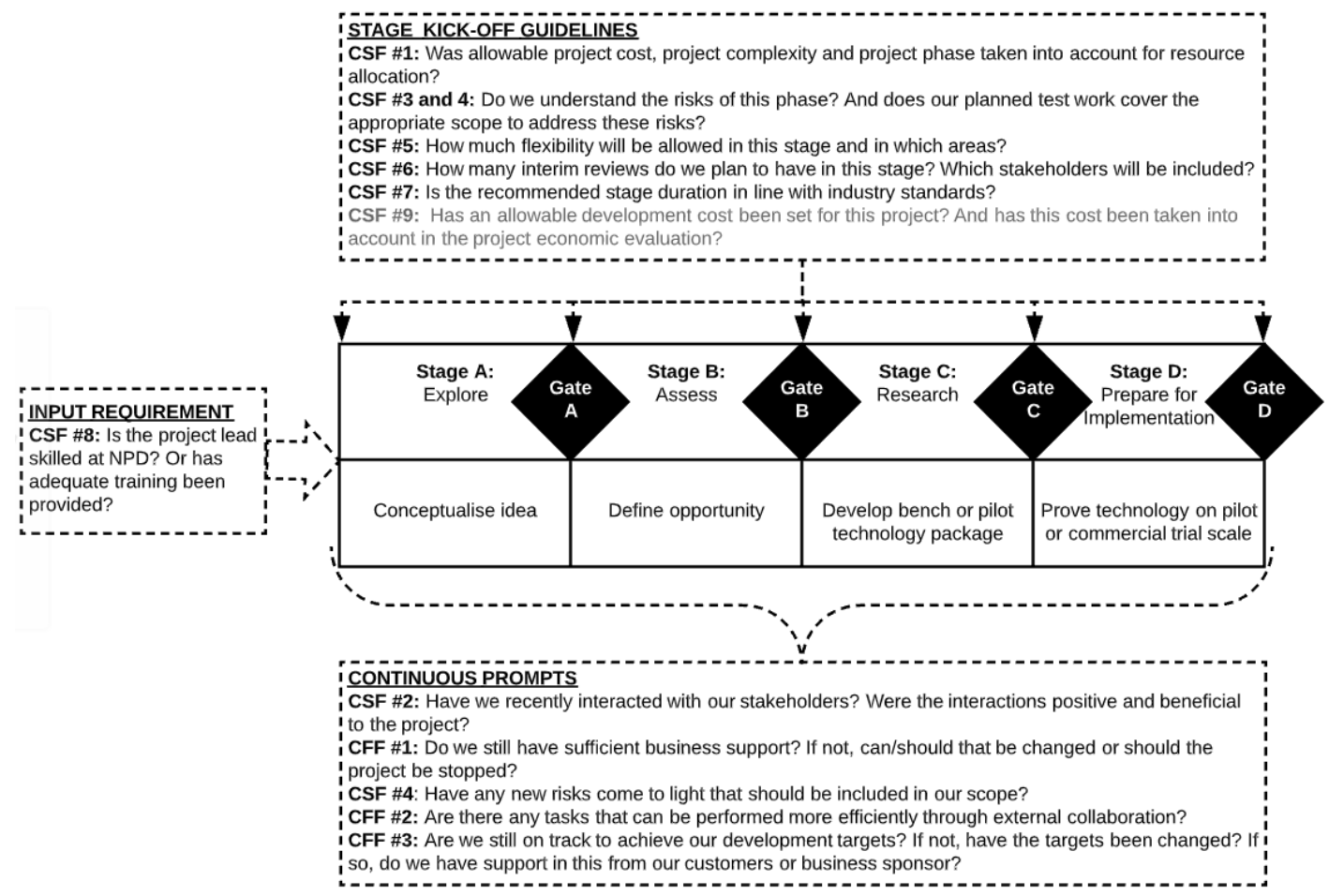

Figure 3: Recommended improvements to the NPD framework of the organisation studied in this research project

- $\quad$ CSF \#5: Flexible NPD process

As new information comes to light when development progresses, the team should be flexible enough to review the new information critically and to decide whether the scope or targets need to be adjusted. It is recommended that the team discuss and agree on an approach to flexibility at the start of each phase.

\section{- $\quad$ CSF \#6: Interim reviews}

Interim reviews are useful platforms to share progress and keep stakeholders informed. It is also a good place to have frank discussions and agree on the next steps when sub-optimal results have been achieved. It is recommended that the frequency of interim reviews be established at the start of each phase.

- CSF \#7: Minimise commercialisation time

NPD best practice studies showed that overall development times, and especially commercialisation times, are continually being shortened. To remain competitive, it is recommended that this organisation take note of typical development times in comparable industries, and use these as guidelines for each phase of NPD projects. Commercialisation strategies and plans should be devised in parallel with later development stages of the product, so that the commercialisation phase is merely a stage of execution.

- CSF \#9: Managing development cost

Tracking allowable development cost is shown in grey in Figure 3, since it has already been implemented in this organisation's NPD framework subsequent to the projects studied in this research. However, it is still shown in Figure 3, as it is seen as an important CSF.

\subsection{Continuous prompts}

- CSF \#2: Relationship management

Relationship management with various stakeholders, such as potential customers and business sponsors, stood out as a significant CSF. It is recommended that the NPD project team regularly be prompted to keep their stakeholders up to date on project progress and ensure that the relationship remains a positive one. 
- CFF \#1: Lack of visionary leadership or business support

One way to foster good relationships with business sponsors is to ensure that the project team continue offering enticing solutions to business problems. Visionary leadership, however, is more challenging to obtain, since it often has more to do with individual characteristics than an outstanding NPD framework.

- $\quad$ CSF \#4: Understanding risk

CSF \#4 has already been listed as a 'stage kick-off guideline', but is also deemed necessary to be included as a 'continuous prompt'. As development progresses, new risks may arise, or may even be introduced by the choices the project team makes. It is recommended that risk identification, analysis, and mitigation discussions be held regularly with the necessary stakeholders.

\section{- $\quad$ CFF \#2: Poor collaboration with external partners}

It seldom happens that an organisation possesses all the skills to complete all their projects. Developing certain skills in-house can take a long time, or bring about hefty carrying costs. It is recommended that the project team be prompted regularly to evaluate whether any of their tasks can be performed more efficiently by an external partner, while taking the cost and schedule impact of this external collaboration into account.

- CFF \#3: Adjusting unmet targets

It has been demonstrated in this work that adjusting unmet targets can be detrimental to a project's success, while evolutionary targets - developed in collaboration with a customer - can work well for a project. It is therefore recommended that the project team be regularly prompted to review their progress towards their targets. If they need to adjust these targets, the team must ensure that they have the business support to make such changes.

\section{CONCLUSION}

The CSFs and CFFs identified and discussed in this study show that certain elements contribute to project success that are not necessarily explicitly captured in the current NPD framework of the organisation studied. Some of these elements are present in third-generation NPD models (i.e., fluidity and adaptability, conditional and situational fuzzy gates, sharper focus of resources and management of portfolios, more flexibility), and in lean development (i.e., continuous customer interaction).

It was suggested that the question is not whether stage gate, agile, or lean is the best NPD process, but rather what blend of practices suits a company best [10]. Therefore updates to the existing NPD framework (to improve NPD success) are proposed, rather than recommending the implementation of an entirely new NPD model. These updates were divided into three categories - input requirements, stage kick-off guidelines, and continuous prompts.

\section{RECOMMENDATIONS}

It is important to reiterate that the findings of this study are based on the case study research of a very small sample of projects. To establish external validity, the results were compared with various literature sources. At this stage, respondent validation was used to establish reliability. Future research should include a larger sample of projects, and possibly extend the target population to several companies.

\section{ACKNOWLEDGEMENTS}

\section{Competing interests}

The authors declare that they have no financial or personal relationships that may have inappropriately influenced them in writing this article.

\section{Author contributions}

C.P. conducted the research and wrote the article. E.v.d.L. and E.P. supervised the project, and provided inputs to the research approach and interpretation of the data. 


\section{Disclaimer}

The views expressed in the submitted article are those of the author and are not an official position of the institution or funder.

\section{REFERENCES}

[1] Barrett, C.W., Musso, C.S. \& Padhi, A. 2009. Upgrading R\&D in a downturn. Accessed on: 25 March 2017. Available: http://www.mckinsey.com/business-functions/operations/our-insights/upgrading-r-and-d-ina-downturn.

[2] Omarjee, L. 2016. Steep drop in Sasol profit on oil price tumble. In News24, Johannesburg. Accessed on: 25 March 2017. Available: https://www.fin24.com/Companies/Industrial/steep-drop-in-sasol-profit-onoil-price-tumble-20160912.

[3] Cooper, R.G. \& Edgett, S.J. 2012. Overcoming the current crunch in NPD resources. In Product Innovation Best Practices Series, 17, Stage-Gate International, pp. 1-19. Accessed on: 27 March 2017. Available: https: //pdfs.semanticscholar.org/1886/7b8c5f41b2f28a9262e66b14618676845618.pdf.

[4] Krishnan, V. \& Ulrich, K.T. 2001. Product development decisions: A review of the literature. Management Science, 47(1), pp. 1-21.

[5] Carter, M.P. 2015. Creation and validation of a best practice new product development process assessment tool for industrial practitioners. Doctoral thesis. College of Technology, Indiana State University, Terre Haute, Indiana.

[6] Kahn, K.B. 2012. The PDMA handbook of new product development, $3^{\text {rd }}$ ed. Hoboken: John Wiley \& Sons.

[7] Markham, S.K. \& Lee, H. 2013. Product development and management association's 2012 comparative performance assessment study. Journal of Product Innovation Management, 30(3), pp. 408-429.

[8] Mallick, D.N. 2015. Impact of development tools on new product development performance. Proceedings on Development Tools, Washington, DC, USA, 060-0023, pp. 1-10. Accessed on: 28 March 2017. Available: https://www.pomsmeetings.org/ConfProceedings/060/Full\%20Papers/final_full_paper.htm.

[9] Loitto, S. 2012. Agile in waterfall: Improving the flexibility of product development. Master's degree in Industrial Management. Helsinki: Helsinki Metropolia University of Applied Sciences.

[10] Anderson, A. 2016. The latest research on product innovation. pp. 1-53. Accessed on: 25 March 2017. Available: http://www.tcsafea.org.cn/imageserver/file/20160419/20160419161731_904.pdf.

[11] Griffin, A., Price, R.L., Vojak, B.A. \& Hoffman, N. 2014. Serial innovators' processes: How they overcome barriers to creating radical innovations. Industrial Marketing Management, 43(8), pp. 1362-1371.

[12] Ries, E. 2011. The lean startup. New York: Crown Business.

[13] Cooper, R.G. 1990. Stage-gate systems: A new tool for managing new products. Business Horizons, 33(3), pp. 44-54.

[14] Preis, E. 2016. Investigating the stage-gate model as an R\&D implementation process in modernising the mining industry. MEng (Mining Engineering) dissertation. Pretoria: University of Pretoria.

[15] Ahmed-Kristensen, S. \& Daalhuizen, J. 2015. Pioneering the combined use of agile and stage-gate models in new product development: Cases from the manufacturing industry. 22nd Innovation and Product Development Management Conference, pp. 2-14.

[16] Cooper, R.G. 1994. Perspective third-generation new product processes. Journal of Product Innovation Management, 11(1), pp. 3-14.

[17] Sommer, A.F., Hedegaard, C., Dukovska-Popovska, I. \& Steger-Jensen, K. 2015. Improved product development performance through agile/stage-gate hybrids: The next-generation stage-gate process? Research-Technology Management, 58(1), pp. 34-45.

[18] Cooper, R.G. 2016. Agile-stage-gate hybrids: The next stage for product development blending agile and stage-gate methods can provide flexibility, speed, and improved communication in new-product development. Research-Technology Management, 59(1), pp. 21-29.

[19] Page, A.L. 1993. Assessing new product development practices and performance: Establishing crucial norms. Journal of Product Innovation Management, 10(4), pp. 273-290.

[20] Balachandra, R. \& Friar, J.H. 1997. Factors for success in R\&D projects and new product innovation: A contextual framework. IEEE Transactions on Engineering Management, 44(3), pp. 276-287.

[21] Griffin, A. 1997. PDMA research on new product development practices: Updating trends and benchmarking best practices. Journal of Product Innovation Management, 14(6), pp. 429-458.

[22] Cooper, R.G., Edgett, S.J. \& Kleinschmidt, E.J. 2002.Optimizing the stage-gate process: What bestpractice companies do - II. Research-Technology Management, 45(6), pp. 43-49.

[23] Ernst, H. 2002.Success factors of new product development: A review of the empirical literature. International Journal of Management Reviews, 4(1), pp. 1-40.

[24] Cooper, R.G., Edgett, S.J. \& Kleinschmidt, E.J. 2004. Benchmarking best NPD practices - III. ResearchTechnology Management, 47(6), pp. 43-55.

[25] Kahn, K.B., Barczak, G. \& Moss, R. 2006. Perspective: Establishing an NPD best practices framework. Journal of Product Innovation Management, 23(2), pp. 106-116.

[26] Barczak, G., Griffin, A. \& Kahn, K.B. 2009. Perspective: Trends and drivers of success in NPD practices: Results of the 2003 PDMA best practices study. Journal of Product Innovation Management, 26(1), pp. 323.

[27] Anderson, A.M. 2008. A framework for NPD management: Doing the right things, doing them right, and measuring the results. Trends in Food Science \& Technology, 19(11), pp. 553-561. 
[28] Panizzolo, R., Biazzo, S. \& Garengo, P. 2010. New product development assessment: Towards a normative-contingent audit. Benchmarking: An International Journal, 17(2), pp. 173-194.

[29] Barczak, G. \& Kahn, K.B. 2012. Identifying new product development best practice. Business Horizons, 55(3), pp. 293-305.

[30] Stage-Gate International. 2017. Benchmarker ${ }^{\mathrm{TM}}$. Accessed on: 25 March $2017 . \quad$ Available: https://www.stage-gate.com/products_benchmarker.php.

[31] Baxter, P. \& Jack, S. 2008. Qualitative case study methodology: Study design and implementation for novice researchers. The Qualitative Report, 13(4), pp. 544-559.

[32] Ismail, N., Nor, M.J.M. \& Sidek, S. 2015. A framework for a successful research products commercialisation: A case of Malaysian academic researchers. Procedia - Social and Behavioral Sciences, 195, pp. 283-292.

[33] Yin, R.K. 2013. Case study research: Design and methods, 5th ed. Thousand Oaks: Sage Publications.

[34] Anderson, C. 2010. Presenting and evaluating qualitative research. American Journal Of Pharmaceutical Education, 74(8), pp. 141-147. 